\title{
The Disproportionate Representation of Black Students within Special Education
}

\author{
Turki Alqarni ${ }^{1, *}$ \\ ${ }^{1}$ Department of Special Education, College of Education, Saint Louis University, USA \\ *Correspondence: Department of Special Education, College of Education, Saint Louis \\ University, USA. E-mail: turki2010m@hotmail.com
}

Received: August 31, 2016 Accepted: September 14, 2016 Published: October 12, 2016

doi:10.5296/ije.v8i4.9964ＵRL: http://dx.doi.org/10.5296/ije.v8i4.9964

\begin{abstract}
The purpose of this research is to discuss the causes of disproportionality of African American students within special education program. Also, this research is discussing the misuse of special education law against this population as well as represents suggestions to reduce the increase of black students in special education. Furthermore, this research has showed previous suggestions to decrease the overrepresentation of black students in special education along with the author's suggestions. The aim of this research is to enhance the concept of inclusion and find methods to increase the inclusion of those marginalized groups in public schools.
\end{abstract}

Keywords: disproportionality, overrepresentation, marginalized students, segregation. 


\section{Introduction}

The role of education around the world is to help all students regardless of their differences such as race, ethnicity, gender or socioeconomic status. However, this role is still in tension in many countries, including the United States, where the education in public schools is not achieving the expectations of different cultural groups such as African American students. This group has suffered from discrimination since their first settlement in the United States. Students within this group were, also, being in a representation of disproportionality because of their racial and ethnic backgrounds. Disproportionate representation by many public schools around the country was given basically to young Black male students, who are often recognized and classified as special needs individuals.

This paper will discuss the disproportionate representation of African American students within special education. The history, key dimensions of this issue, and recent practices by many public schools regarding this issue will be mentioned. Furthermore, some recommendations will be introduced in order to present a solution for some concerns and inappropriate practices by public schools toward young black male students.

\subsection{Definitions of Disproportionate Representation of Black Students}

According to Oxford Dictionary, the word disproportionate means "the state of two things not being at an equal high or low level.” According to the National Education Association of the United States and National Association of School Psychologists (2007), the term disproportionality in special education is "the overrepresentation and under-representation of a particular population or demographic group in special or gifted education programs relative to the presence of this group in the overall student population” (p. 6). In this regard, it has been widely known that some public school teachers foresee students from the dominant society more than students from other cultural backgrounds. Basically, when teachers' attitudes and reactions are absent when delivering their lessons to all students compared to being biased in favors of the dominant class, it can easily cause a feeling of rejection among some students (Winzer \& Mazurak, 2000). For instance, 2.64\% of all Black male students who joined public education are nationally recognized as having intellectual disabilities (Gentry, 2009). Moreover, disabled African American student are seen as underrepresented in public schools general education and overrepresented in isolated classroom situations (Skiba, Poloni-Staudinger, Gallini, Simmons, \& Feggins-Azziz, 2006).

\section{The History of Disproportionality of Black Students}

The history of disproportionate practices by schools, including teachers, toward African American groups has been rooted since early years until 1950s (Skiba, Simmons, Ritter, Gibb, Rausch, Cuadrado, \& Chung, 2008). These practices were seen as forms of discrimination and oppressions, especially in school levels where African American students have witnessed. Moss (2009) reported that African American students resorted to self-education in order to survive their daily life from oppressions they had by European-Americans. 
Fortunately, the advent of the Civil Rights movement in 1950s and 1960s opened doors for a more acceptable admission process to public schools (Winzer \& Mazurek, 2000). Notable educational scholars started to advocate for equal access of education regardless of ethnicity or race. Some of these are William Cruickshank (1958), Lloyd Dunn (1968), Gunnar Dybwad etc. who all fought against racial discrimination in the educational system. These people were believed to be the pioneers of modern advocates for equality.

Later, federal policies emerged to confront the separation in public schools, for example, Rehabilitation Act of 1973, and Education for all Handicapped children 1975, which were addressing IQ tests and lack of educational chances given to African American students, which led them to be isolated within special classes. Also, IDEA 2004 allowed states to monitor and review the local implementations and procedures towards disproportionality of racial or ethical groups (Skiba, et al, 2008). These policies will be further explained later on this paper as initiatives against disproportionality of African Americans in special education.

There are some dimensions regarding the disproportionality of African American students in special education, but the two key dimensions which can be noted form the definition of disproportionate representation; the overrepresentation and under-representation of students.

The overrepresentation in special education is known as when a racial group is largely represented in the program than its percentage of the entire educational system or in a categorized disability; for example, Mild Mental Retardation (MMR). According to US Department of Education NCES (2000), 9\% of black male students are represented of the total enrollees to public education; however $20 \%$ of those students are classified as having mental retardation. Moreover, 21\% of black students are identified as learning disabilities and $12 \%$ of black students are identified as emotional disturbance (Lawson, Q., Humphrey, Wood-Garnett, Fearn, Welch, Greene-Bryant, \& Avoke, 2002)..

On other hand, it is widely believed that the under-representation in special education when the number of a racial group is considerably less to receive special education services than its overall number of the education system. According to the National Academy of Sciences report, only 3.4\% of black students are categorized to giftedness (National Education Association of the United States, \& National Association of School Psychologists, 2007). The image of under and over-representation of African American students is indeed one of the present oppression in the education system towards this population.

\section{Causes of Disproportionality of Black Students within Special Education}

It is not undeniable that the majority of black students are currently experiencing negative practices in public schools, which re-picture the previous discrimination they had. African American students still face oppression in the modern-day educational system (Weatherspoon, 2014). These students are still marginalized by their teachers through providing inadequate effort in teaching and conveying information.

Winzer and Mazurak (2000) described the education system as part of the "ever-changing 
society”, characterized by diversity including the increase of African-American enrolled in elementary and secondary public schools. The premise of her book is to focus more on preparing teachers in the challenges facing multicultural education. She mentioned the rise of African-American students in regular schools should not be equated to an increase in enrollees in special education. Rather than classifying those Black students as illiterates, the teachers should undergo a restructuring or a reform in creating lesson plans that will easily be understood by a class of students with racial backgrounds.

Consequently, Weatherspoon (2014) discussed that African-American male students today are more likely to be excluded from taking preparatory courses needed for college admission. The premise for this indecent act is due to some school's bias assuming that these students are not capable of making it to the post-secondary level of education. This mentality that schools inculcate in the minds of African-American students often leads to self-fulfilling prophecies. Those students tend to have a low self-esteem and expectations regarding their potential. In turn, they settle for mediocre and low-paying jobs that they believe are fit for them. Furthermore, the effect of the segregation that these marginalized students experience often leads to higher rate of dropout.

Aside from discriminatory segregation in regular schools, there are also evident cases throughout the country of overrepresentation of African-American students in special education. This disproportionate representation of black students in special education is due to unfair classification regarding literacy and intellectual capacity. Belgrave and Brevard (2015) cited the National Education Associations (NEA) findings about Black boys in special education. According to NEA's research in 2011, almost $80 \%$ of youth in special education are African Americans and Hispanics. Also, even though Black male students are considered minority, with a population of only $9 \%$, they still comprise the $20 \%$ of all students in the United States classified as mentally retarded.

Additionally, this disproportionate representation of African-Americans in special education is generally believed to be an implication of crisis in civil rights violation linked to schools' policies and admission process. In other words, the restrictive school setting forced to African-American boys to be in a continuous plight that they have to face in order to learn basic literacy even if they are capable to do it even in a regular school.

A number of variables lead to the increasing number of African-American students in special education. These students who are at risk of educational failure may actually be caused by lack of appropriate teachers. Some teachers are used to educating the more dominant class and failed to acknowledge the sociocultural needs of some students. Their attitudes and reactions toward African-American students are crucial in delivering their lessons. The classroom climate depends on the way they react to the presence of a more diverse classroom. Being bias to the dominant class can easily cause a feeling of rejection to some students (Winzer \& Mazurak, 2000).

The increase of African American males in special education is also caused by several factors that have been present in our society. One of which is the low social and academic expectations towards African Americans (Wenzel, 2008). Due to these unfair perceptions for 
African-American children, they are often classified to a special education class leading to a disproportionate representation of Black pupils. The consequences of being in special education class, which is perceived as a dead-end for African-American students, vary from eventual poor employment and low wages to development of poor identity and low self-esteem. It can also lead students to incarceration and increased dropout rates.

According to Kirkland (2013), the struggles that most African Americans face in regular high school are rooted to their detached emotions towards their teachers. Their indifference in finishing school and learning their courses was because of the school's administrators and teachers' lack of initiative to address the illiterate black students. Moreover, this crisis is due to the discriminated students' fear to voice out the internal struggles they are in. Most educators conclude that the silence of these African Americans is a sign of unwillingness to learn the subject at hand, thus causing a more chaotic relationship between the African American students and their teachers.

The silence that these Black children display in school is due to the tacit discrimination of the society regarding their literacy. For these Black children, revealing their high literacy rate is tantamount to social death or great humiliation. They believe that it is best for them to stay silent whenever a teacher asks a question than enthusiastically participate in classroom activities.

Kirkland (2013) further divulged in his book the problematic definition of "literacy" to most educational institutions. According to him, African Americans are often tagged as illiterate because of their lack of capability to read, write, and do basic arithmetic. However, he discussed that the concept of literacy is on a continuous process of changing. The definition of literacy more likely depends on people who have the power to define it. Their silence is often equated to illiteracy that eventually leads to their classification fit for a special education setting.

Noguera (2003), on the other hand, argued in his book that the public education system should first and foremost be the hope for marginalized class such as African Americans. This institution should promote a conducive learning environment for everyone regardless of age, race, or gender. However, urban public schools often inculcate the idea that African-American students lag behind White students. It was widely assumed that due to their color and lower living standard, these Black students are neglected of their success.

Aside from constituting the majority of students enrolled in special education, researches showed that African-American students also compose the majority of students who are suspended or expelled from school. Citing disciplinary reasons as the cause of this underwhelming fate of Black students, these cases fuel the racial slurs often shared in schools (Noguera, 2003).

\section{The Misinterpretation of US Law Regarding African American Students' Rights}

The U.S. Department of Education, Office of the Civil Rights (USDoE-OCR) has been 
actively investigating this misidentification against African-American students in general education system. According to the OCR, this overrepresentation of minority class paves the way for a less motivational environment for Black students (Weatherspoon, 2014).

Through the years, a number of policies have been passed to address the civil crisis that these African-American students face in school. However, not all policies served its purpose to protect the rights of marginalized individuals. In 1975, the Congress passed the Individuals with Disabilities Act (IDEA) but it was eventually used unsparingly to classify African-American males in special education programs (Weatherspoon, 2014).

The policy that was supposed to uphold the rights of physically and mentally challenged students, was used to suspend and expelled African-American males with mental disabilities from school in accordance to the necessary services required by the IDEA. It was only reauthorized and amended in 2004 to cater to a more specific sector in order to address the mislabeling and disproportional dropout rate of African-American males.

The Rehabilitation Act of 1973 and the Education for all Handicapped Children Act of 1975 both uphold the right of African Americans against racially and culturally biased and discriminatory IQ tests that purposively put them to a special education class. Several years after the passage of these bills, however, African-American males still face their unfair fate of being disproportionately placed in a special class.

One perfect example of this phenomenon is the Larry P. case. Rothstein and Johnson (2014) found out in their research that the Larry P. plaintiffs questioned the integrity of some IQ tests used for placement of African-American students in "Educable Mentally Retarded (EMR)" classes. According to the plaintiffs, these EMR classes were not the solution to the literacy problem of Black students but rather deemed to be a dead-end one for enrolled students. These classes do not provide the necessary support system for the students to return to regular classes and just provide training to make them socially useful.

Evidences presented at the Larry P. trial proved that EMR classes tend to provide no significant support for students as they only fell further behind than students in regular classes. Fortunately, the court ordered for a more standardized intelligence tests that will reevaluate every African-American child who are classified as an EMR pupil. Furthermore, the court ordered to eradicate the disproportionate placement of African-American children in EMR classes (Rothstein \& Johnson, 2014).

\section{Previous Suggestions}

According to Obiakor and Ford (2002), for African-American students to acquire a far better quality of treatment in special education, teachers and policymakers should acquire the necessary knowledge in devising learning strategies fit for their children. Educators should have a far better understanding of their culture and experiences to be able to make appropriate lesson plans. They also suggested that African Americans should have equal educational opportunities as European Americans. This means that learning should be more 
familiar to them through the use of their own cultural lenses and references. In this way, they will be more motivated to attend and participate in class.

A culturally responsive teaching is also encouraged in order to eradicate the notion of their subpar being as students and to promote their dignity as intellectually and socially developed individuals.

On the other hand, Wenzel (2008) suggested that an implementation of remedial reading programs at all K-12 levels may be a solution to the overrepresentation of African-American students in special education. Moreover, she suggested that it's high time to recruit more racially or ethnically diverse teachers to improve the home-school communication and collaboration to diffuse the growing numbers of Black pupils in special education.

Since African-American parents often feel unwelcome in attending school events, an intervention between teachers and parents should be devised. This will open a more harmonious relationship between the two parties and can be a better form of support system for children struggling in school. Parents of African-American children should be able to voice out their thoughts without feeling intimated among the group of White parents. In this way, the communication between school administrators and parents will be more open and problems will become easier to resolve.

Special education programs should contain an extensive preparation in line with enhancing the teachers' awareness and sensitivity of the cultural values of their pupils. Their ethics towards facilitating diverse students should also be tested in order to ensure appropriate interactions to their students (Winzer \& Mazurak, 2000). These educators should veer away from homogeneity and stereotypical beliefs in order to unfold the best potential of their students in special education.

\section{The Author's Suggestions}

Indeed education plays a vital role in improving the livelihood of individuals regardless of race. A high educational attainment can lead to a more competitive salary, and fulfilling jobs. May it be from a regular school or a special education, all should have equal opportunities for a tertiary education that can have their way for a more successful life. The educators should put necessary efforts to their students' future.

Educational institutions should strengthen its advocacy for a more institutionalized assessment of students who are deemed fit for special education. It should be taken note that personal bias and homogeneity should be clearly avoided in classifying students. Race, gender, or age should not be considered as determining factors in putting a student in a special care. A fair and just system should be thoroughly upheld for African Americans who are challenged when it comes to literacy.

Aside from school administrators and educators, policymakers should also strengthen the promotion for equal access in education. Bills that protect the civil rights of students such as African Americans should be strongly implemented in order to motivate more of them to 
attend and participate in formal schooling. Not only will this help the development of individuals but can also promote the progress of the nation.

Lastly, mass media should revolutionize its portrayal of African Americans. They should report more of the success of these Black students despite the pressure that they encounter in school. This will greatly help in eradicating prejudice among them in school.

\section{Conclusion}

Since the 1800s, African Americans have been suffering from unfair treatment in the educational system. Because majority of attendees in regular schools are Whites, African-American students are faced with numerous predicaments just to learn the same courses that the other students who belong to the dominant group do. Moreover, the gravest act of discrimination in misclassifying Black students as mentally handicapped should be the main concern of policymakers and educators in regular public schools. Putting them in special classes instead of understanding their needs first greatly neglects the self-development of these students. This problem greatly delimits the potential of African-American students that is also not helpful in the progress of the country. With appropriate policies to be passed by lawmakers, a better future for these African Americans can be protected and ensured. Teachers and school administrators should also strengthen their understanding in multicultural classroom setting. In this way, they will be more adept in conveying learning to their students. African American children deserve the equal opportunity of education enjoyed by other White students. They should not be judged based on their skin color and physical attributes but rather be assessed based on their academic performance after receiving an equal amount of effort from their teachers. Lastly, their silence should not be tolerated but rather be a sign to encourage them to participate and excel in the best possible way they can.

\section{References}

Belgrave, F., \& Brevard, J. (2015). African American Boys: Identity, Culture, and Development. Richmond: Springer. http://dx.doi.org/10.1007/978-1-4939-1717-4

Gentry, R. (2009). Disproportionate Representation of Minorities in Special Education--How Bad?. Online Submission.

Kirkland, D. (2013). A Search Past Silence. New York: Teachers College Press.

Lawson, Q., Humphrey, L., Wood-Garnett, S., Fearn, K., Welch, C., Greene-Bryant, B., \& Avoke, S. (2002). Addressing Over-Representation of African-American Students in Special Education. Arlington, VA: The Council for Exceptional Children, available online, 1-54.

Moss, H. (2009). Schooling Citizens: The Struggle for African American Education in Antebellum America. Lynchburg: The University of Chicago Press. http://dx.doi.org/10.7208/chicago/9780226542515.001.0001 
National Education Association of the United States, \& National Association of School Psychologists. (2007). Truth in labeling: Disproportionality in special education. National Education Assn.

Noguera, P. (2003). City Schools and the American Dream. New York: Teachers College Press.

Obiakor, F., \& Ford, B. (2002). Creating Successful Learning Environments for African American Learners with Exceptionalities. Thousand Oaks: Corwin Press, Inc.

Rothstein, L., \& Johnson, S. (2014). Special Education Law(5th Ed.). Thousand Oaks: SAGE Publications, Inc.

Skiba, R. J., Poloni-Staudinger, L., Gallini, S., Simmons, A. B., \& Feggins-Azziz, R. (2006). Disparate access: The disproportionality of African American students with disabilities across educational environments. Exceptional Children, 72(4), 411-424.

Skiba, R. J., Simmons, A. B., Ritter, S., Gibb, A. C., Rausch, M. K., Cuadrado, J., \& Chung, C. G. (2008). Achieving equity in special education: History, status, and current challenges. Exceptional Children, 74(3), 264-288.

Weatherspoon, F. (2014). African-American Males and the U.S. Justice System of Marginalization: A National Tragedy. New York: Palgrave Macmillan. http://dx.doi.org/10.1057/9781137408433

Wenzel, S. (2008). The Future of African American Male Students in Special Education: A Delphi Study. Minneapolis: Walden University.

Winzer, M., \& Mazurek, K. (2000). Special Education in the 21st Century: Issues of Inclusion and Reform. Washington: Gallaudet University Press.

\section{Copyright Disclaimer}

Copyright for this article is retained by the author(s), with first publication rights granted to the journal.

This is an open-access article distributed under the terms and conditions of the Creative Commons Attribution license (http://creativecommons.org/licenses/by/3.0/). 